\title{
2013 ve 2018 Fen Bilimleri Öğretim Programlarının Genel Eğilimler ve
} Yaklaşımlar Açısından Karşılaştırılması

\section{Bahar CANDAŞ*, Zeynep KIRYAK ${ }^{* *}$, Ayşe KILINÇ***, Onurhan GÜVEN**** ve Haluk ÖZMEN ${ }^{* * * * *}$}

Öz: Bu çalışma, 2013 ve 2018 Fen Bilimleri Dersi Öğretim Programlarının çeşitli değişkenler açısından karşılaştırılması amacıyla gerçekleştirilmiştir. Çalışmada nitel araştırma yaklaşımı benimsenmiş ve doküman analizi deseninden yararlanılmıştır. Öğretim programlarında benimsenen yaklaşımlar, genel amaçlar ve eğilimler, öğrenme alanları, öğretmen-öğrenci rolleri, benimsenen yöntem ve stratejiler ve ölçme değerlendirme yaklaşımları boyutları altında sunulmuştur. Öğretim programlarında bilgi öğrenme alanında meydana gelen değişimler ise kazanım sayıları, ders saatindeki değişim ve içerikteki değişimler boyutlarında incelenmiştir. Çalışma sonucunda, yeni öğretim programının 21. yüzyıl becerilerinin geliştirilmesini merkeze aldığı belirlenmiştir. $\mathrm{Bu}$ doğrultuda, programın uygulayıcıları olan Fen Bilimleri öğretmenlerinin yeterli donanıma sahip olabilmeleri için hizmet öncesi ve hizmet içi eğitimlerle desteklenmeleri önerilmektedir.

Anahtar Kelimeler: Fen Bilimleri, öğretim programı inceleme, fen bilimleri dersi öğretim programı, doküman analizi

\footnotetext{
* Arş. Gör. Bahar CANDAŞ, Trabzon Üniversitesi, Fatih Eğitim Fakültesi, Matematik ve Fen Bilimleri Eğitimi Bölümü, Email: bhrcnds@gmail.com Orcid No: 0000-0003-4516-9670

** Arş. Gör. Zeynep KIRYAK, Trabzon Üniversitesi, Fatih Eğitim Fakültesi, Matematik ve Fen Bilimleri Eğitimi Bölümü, Email: zeynepkiryak@gmail.com Orcid No: 0000-0002-8644-4336

${ }^{* * *}$ Arş. Gör. Ayşe KILINÇ KANLI, Trabzon Üniversitesi, Fatih Eğitim Fakültesi, Matematik ve Fen Bilimleri Eğitimi Bölümü, Email: kilinc.aysee@hotmail.com Orcid No: 0000-0002-9408-2865

${ }_{* * * *}^{*}$ Arş. Gör. Onurhan GÜVEN, Trabzon Üniversitesi, Fatih Eğitim Fakültesi, Matematik ve Fen Bilimleri Eğitimi Bölümü, Email: onrhngvn@gmail.com Orcid No: 0000-0002-6749-2578

${ }^{* * * * * *}$ Prof. Dr. Haluk ÖZMEN, Trabzon Üniversitesi, Fatih Eğitim Fakültesi, Matematik ve Fen Bilimleri Eğitimi Bölümü, Email: hozmen61@hotmail.com Orcid No: 0000-0003-0578-3481
}

Bu çalışmanın bir kısmı X. Uluslararası Eğitim Araştırmaları Kongresi’nde sözlü bildiri olarak sunulmuştur. 


\section{Comparison of 2013 and 2018 Science Curriculums in Terms of General Trends and Approaches}

Abstract: This study was carried out to compare 2013 and 2018 Science Education Curriculums in terms of various variables. Document analysis method was used in this qualitative study. The variables subjected to analyze were general objectives and trends, learning domain, teacher-student roles, methods and strategies, assessment and evaluation, objectives, lesson hours and content. Consequently, it has been determined that the new curriculum has centered on developing students' 21st century skills. In this respect, it is recommended that science teachers should be supported with pre-service and in-service training in order to have expected competence.

Keywords: Science Education, curriculum analyze, science education curriculum, document analysis

\section{Giriş}

Bilim ve teknoloji dünyasındaki hızlı değişmeler, ülkelerin refah seviyesinin ve bireylerin yaşam standartlarının yükselmesi, büyük şirketlerin çalışan profiline yönelik talepleri, toplumların ihtiyaç ve beklentilerindeki artış, günümüz insanının sahip olması gereken becerilere yönelik beklentileri de değiştirmiştir. $\mathrm{Bu}$ anlamda, çağdaş toplumlarda eğitimden beklenen, ezberleyerek öğrenen ve sorulduğunda bilgiyi anlamlandırmadan tekrarlayan bireyler yetiştirmekten ziyade, 21. yüzyıl becerileri olarak adlandırılan bilgiyi sorgulayan, yorumlayan, yeniden anlamlandıran, eleştirel düşünen, sahip olduğu bilgileri günlük yaşama uyarlayan ve karşılaştığı problemleri çözebilen bireylerin yetiştirilmesidir (Yıldırım ve Şimşek, 1999). Küresel bağlamda yapılan değişiklikleri takip edebilmek ve toplumu bu doğrultuda yönlendirmek için hükümetler, bu becerileri öğretim programlarına, dolayısıyla eğitim sistemlerine entegre ederek, bu becerilere sahip öğrenciler yetiştirmeyi hedeflemektedir. 21 . yüzyıl becerilerine sahip öğrencilerin yetiştirilebilmesi, öğretim sürecinde öğrencinin aktif olması, araştırması, sorgulaması ve bilgiyi kendisinin yapılandırması gerektiğine vurgu yapan yapılandırmacı yaklaşımın öğretim sürecinde kullanılması ile mümkün olabilecektir. Bu beklentiler aynı zamanda okullarda Fen Bilimleri derslerinin okutulmasının gerekçelerinden birisi olan "fen okuryazarı" bireyler yetiştirilmesi hedefi ile de örtüşmektedir. Dünyadaki uygulamalara ve çağdaş anlayışlara benzer şekilde ülkemizde de özellikle fen bilimlerinden 
beklentilerin gerçekleştirilmesi adına, 2004 yılından itibaren öğretim programları yapılandırmacı bir anlayışla hazırlanmaya başlanmıştır. 2005 yılından itibaren okullarda uygulanmaya başlanan "Fen ve Teknoloji” dersi, hem yapılandırmacı felsefeyi yansıtması hem de bu felsefeye dayalı olarak, öğrenci ve öğretmen rollerinde değişime yol açarak ölçme ve değerlendirme anlayışında da değişikliğe gitmesi açısından önem taşımaktadır.

Fen ve Teknoloji dersi, klasik Fen Bilimleri dersi içeriğini ve uygulanma biçimini önemli ölçüde değiştirmiş olsa da uygulanması sürecinde yaşanan değişik sorunlar ve zaman içerisinde doğan güncelleme ihtiyaçları, 2013 yılında hem dersin adının değişmesi hem de içeriğinde bazı değişikliklerin yapılmasıyla Fen Bilimleri Dersi Öğretim Programı’nın hazırlanması sonucunu doğurdu. 2012-2013 yılında temel eğitim sisteminin değişmesi, Fen ve Teknoloji dersi içeriğinde yer alan kazanım sayılarının ve bilgi miktarının oldukça fazla olması, tutum ve değerlere yönelik kazanım sayılarının yetersizliği, programda 21. yüzyıl becerilerine yeterince yer verilmemesi ve yapılandırmacılık odaklı bir yaklaşımdan çağdaş yaklaşımları da içeren daha karma bir öğretim anlayışına geçilmesi ihtiyacı, Fen ve Teknoloji dersinin güncellenmesi gerektiğine yönelik ileri sürülen en önemli gerekçeler arasında sayılmaktadır (Ayas ve diğg., 2016).

21. yüzyıl becerilerinin geleneksel eğitim anlayışı ile kazandırılmasının mümkün olmadığı düşünülmektedir. Bu nedenle, bilim, teknoloji, matematik ve mühendislik içeriklerinin disiplinler arası yaklaşımla öğretilmesi ve pratik uygulamaların hayata değer katacak yeniliklere dönüşmesi fikriyle ortaya çıkan FeTeMM (Fen, Teknoloji, Matematik ve Mühendislik) yaklaşımı özellikle Amerika'nın eğitim politikasında önemli bir yer bulmaktadır (Akgündüz ve Ertepınar, 2015). Ortaya çıkan bu akımı öğretim programlarına adapte eden ülkelerin sayısının artması ve bu yaklaşımın gerektirdiği becerilere sahip bireyler yetiştirme isteği öğretim programlarında güncelleme yapılması ihtiyacını ortaya çıkarmıştır. Bu doğrultuda, ülkemizde de 2017 yılında yeni Fen Bilimleri Dersi Öğretim Programı yayımlanmıştır. Ancak, 2018 yılının başlarında Fen Bilimleri Dersi Öğretim Programı 2017 programında yapılan bazı değişikliklerle yeniden sunulmuştur.

Fen Bilimleri dersi öğretim programlarına yönelik olarak gerçekleştirilen çalışmalara bakıldığında, araştırmacıların uygulamada olan bir programı kendi içinde çeşitli boyutlarda inceledikleri ya da bir önceki programla yeni düzenlenen program arasındaki benzerlik ve farklılıkları ortaya çıkaracak karşılaştırmalı çalışmalar yürüttükleri görülmektedir. Özdemir (2006), 2005 yılında uygulanmaya başlanan Fen ve Teknoloji Dersi dördüncü ve beşinci sınıf 
öğretim programında öğretmenlerin karşılaştıkları sorunları ve çözüm önerilerine ilişkin görüşlerini incelemiştir. Tekbıyık ve Akdeniz (2008) tarafından gerçekleştirilen çalışmada, Fen ve Teknoloji Dersi Öğretim Programı'nın etkililiği ve başarısına inanma bağlamında, öğretmenlerin programı kabullenmelerine ve uygulamalarına yönelik görüşleri belirlenmiştir. Bağcı-Kılıç, Haymana ve Bozyılmaz'ın (2008) çalışmasında, Fen ve Teknoloji Dersi Öğretim Programı, bilim okuryazarlığının değişik boyutları ve bilimsel süreç becerileri açısından incelenmiştir. Demirbaş (2008) tarafından gerçekleştirilen çalışmada, 2000 ve 2005 altıncı sınıf Fen Öğretim Programları karşılaştırmalı olarak incelenmiştir. Karatay, Timur ve Timur (2013) ise, yürüttükleri çalışmada 2005 ve 2013 Fen Bilimleri Dersi Öğretim Programları'nı ders saatleri, kazanım sayıları, konu alanı, üniteler, öğrenme-öğretme yaklaşımları ve fen okuryazarlığı boyutlarında karşılaştırmışlardır. Özata-Yücel ve Özkan (2013) tarafından yürütülen çalışmada 2005 ve 2013 Fen Bilimleri Dersi Öğretim Programları çevre konuları açısından değerlendirilmiştir. Kubat (2015), öğretmenlerin beşinci sınıf Fen Bilimleri Dersi Öğretim Programı’na yönelik içerik ve kazanım ilişkisi açısından yaptıkları değerlendirmeleri incelemiştir. Toraman ve Alcı (2013) ve Karaman ve Karaman (2016) Fen Bilimleri öğretmenlerinin 2013 Fen Bilimleri Dersi Öğretim Programı’na yönelik düşüncelerini ortaya çıkarmak amacıyla çalışmalar yürütürken, Özcan ve Düzgünoğlu (2017) tarafından on Fen Bilimleri öğretmeni ile gerçekleştirilen çalışmada, öğretmenlerin Fen Bilimleri Dersi 2017 Taslak Öğretim Programı’na ilişkin görüşleri belirlenmiştir. Bahar, Yener, Yılmaz, Emen ve Gürer (2018) tarafindan yürütülen çalışmada, 2013, 2017 ve 2018 Fen Bilimleri Dersi Öğretim Programları'nda yer alan kazanımlardaki değişimler incelenmiş ve programlar arasındaki farklılıklar fen, teknoloji, matematik ve mühendislik boyutları açısından ortaya çıkarılmaya çalış1lmıştır. Güneş-Koç ve Kayacan (2018) ise, 2018 Fen Bilimleri Dersi Öğretim Programı'nda yer alan mühendislik ve tasarım becerilerine yönelik öğretmen görüşlerini belirlemiş̧lerdir. Gerçekleştirilen çalışmalara bakıldığında, 2000, 2005 ve 2013 öğretim programlarının incelendiği çalışmalarda programın bütünü hakkında çeşitli boyutlarda sonuca ulaşmaya çalışılırken, güncel öğretim programı üzerine yapılan çalışmalarda genel anlamda FeTeMM boyutunun etkililiği, programdaki yeri, öğretmen görüşlerinin belirlenmesi gibi amaçlarla çalışmaların yürütüldüğü görülmüş̧ür. Bu nedenle, bu çalışmanın güncel öğretim programının bütünü hakkında öğretmenlere ve araştırmacılara fikir verme açısından önem arz ettiği düşünülmektedir. 
Bu çalışmada, 2013 ve 2018 Fen Bilimleri Dersi Öğretim Programlarının çeşitli değişkenler açısından karşılaştırmalar yapılarak incelenmesi, bu doğrultuda 2018 öğretim programının farklı açılardan yorumlanması ve öğretmenlere, araştırmacılara ve program geliştiricilere fayda sağlayacağı düşünülen önerilerin sunulması amaçlanmıştır. Çalışma, "2013 ve 2018 Fen Bilimleri Dersi Öğretim Programlarının yaklaşımlarında yapılan değişiklikler” ve “2013 ve 2018 Fen Bilimleri Dersi Öğretim Programlarının bilgi öğrenme alanlarında yapılan değişiklikler” olmak üzere iki ana başlık altında incelenmiştir. Her bir başlık kendi içinde alt başlıklara ayrılarak kapsamlı bir şekilde ele alınmıştır.

\section{Yöntem}

Çalışmada nitel araştırma yaklaşımı benimsenmiş ve doküman analizi deseninden yararlanılmıştır. Doküman analizi, incelenmesi amaçlanan konuya yönelik yazılı bilgi kaynaklarının analizini içermektedir (Yıldırım ve Şimşek, 2013). Bu araştırma deseninde belirli kategoriler ve temalar altında belgelerin kodlanması amaçlanmaktadır. Bu çalışmada ilk olarak Millî Eğitim Bakanlığı tarafından yayımlanan 2013 ve 2018 Fen Bilimleri Dersi Öğretim Programları genel hatlarıyla incelenmiş ve verilerin hangi temalar altında sunulacağı belirlenmiştir. Bulgular öğretim programlarında benimsenen yaklaşımlar, genel amaçlar ve eğilimler, öğrenme alanları, öğretmen-öğrenci rolleri, benimsenen yöntem ve stratejiler ve ölçme değerlendirme yaklaşımları boyutları altında sunulmuştur. Öğretim programlarında bilgi öğrenme alanında meydana gelen değişmeler ise kazanım sayıları, ders saatindeki değişim ve içerikteki değişimler boyutlarında incelenmiştir. Belirlenen temalar altında 2013 ve 2018 Fen Bilimleri Dersi Öğretim Programları dört araştırmacı tarafından ayrı ayrı analiz edildikten sonra sonuçlar karşılaştırılmış ve kodlayıcılar arası uyum \%98 olarak hesaplanmıştır. Veriler bir fen bilimleri eğitimi uzmanı tarafından incelendikten sonra belirlenen temalar altında bulgular düzenlenmiştir.

\section{Bulgular}

2013 ve 2018 Fen Bilimleri Dersi Öğretim Programları “2013 ve 2018 Fen Bilimleri Dersi Öğretim Programlarının yaklaşımlarında yapılan değişiklikler” ve "2013 ve 2018 Fen Bilimleri Dersi Öğretim Programlarının bilgi öğrenme alanlarında yapılan değişiklikler” olmak üzere iki ana başlık altında incelenmiştir. İlk başlık altında 2013 ve 2018 Fen Bilimleri Dersi Öğretim Programlarının amaçları, öğrenme alanları, öğretmen-öğrenci rolü, benimsenen yöntem ve 
stratejiler ile ölçme değerlendirme yaklaşımları boyutlarında elde edilen bulgulara yer verilirken; ikinci başlık altında bilgi öğrenme alanındaki kazanımların sayısı ve yapısı, kazanımların bulundukları sınıf düzeyleri ve üniteler, ders saatlerindeki değişiklikler boyutlarında elde edilen bulgulara yer verilmiştir.

\section{3 ve 2018 Fen Bilimleri Dersi Öğretim Programlarının Yaklaşımlarında Yapılan}

\section{Değişiklikler}

\section{3 ve 2018 Fen Bilimleri Dersi Öğretim Programlarının Amaçları Açısından Karşılaştırılması}

2013 ve 2018 Fen Bilimleri Öğretim Programları'nın amaçlarına yönelik olarak yapılan karşılaştırma sonucu elde edilen bulgular Tablo 1'de verilmiştir.

Tablo 1

Öğretim Programlarının Amaçlar Açısından Karşılaştırılması 2013 2018

Biyoloji, fizik, kimya, yer, gök ve çevre bilimleri, sağlık ve doğal afetler hakkında temel bilgiler kazandirmak Astronomi, biyoloji, fizik, kimya, yer ve çevre bilimleri ile fen ve mühendislik uygulamaları hakkında temel bilgiler kazandırmak

Bilimin toplumu ve teknolojiyi, toplum ve teknolojinin de bilimi nasıl etkilediğine Karşılı̆̆ yok ilişkin farkındalık geliştirmek Bilimin, tüm kültürlerden bilim insanlarının ortak çabası sonucu üretildiğini anlamaya katkı sağlamak ve bilimsel çalışmaları takdir Karşılığı yok etme duygusunu geliştirmek Bilimin, teknolojinin gelişmesi, toplumsal sorunların çözümü ve doğal çevredeki ilişkilerin anlaşılmasına olan katkısını takdir Karşılı̆̆1 yok etmeyi sağlamak

Doğada meydana gelen olaylara ilişkin merak, tutum ve ilgi geliştirmek

Doğada ve yakın çevresinde meydana gelen olaylara ilişskin ilgi ve merak uyandırmak, tutum geliştirmek

Sosyobilimsel konuları kullanarak

Sosyobilimsel konuları kullanarak bilimsel düşünme alışkanlıklarını geliştirmek muhakeme yeteneğ $i$, bilimsel düşünme alışkanlıkları ve karar verme becerileri geliştirmek

Evrensel ahlak değerleri, millî ve kültürel

Karşıllı̆̆ yok değerler ile bilimsel etik ilkelerinin benimsenmesini sağlamak

Tablo 1'den görüldüğü gibi, 2013 öğretim programında yer alan bazı amaçlara 2018 öğretim programında yer verilmediği, 2018 öğretim programına ise yeni bir amacın eklendiği 
belirlenmiştir. 2013 ve 2018 öğretim programları genel amaçları ve eğilimleri açısından incelendiğinde, iki öğretim programında da bütün bireylerin fen okuryazarı olarak yetiştirilmesinin amaçlandığı görülmüş ve bu doğrultuda 2013 öğretim programında 12 alt amaçtan bahsedilirken, 2018 öğretim programında 10 alt amaçtan bahsedilmiştir.

\section{3 ve 2018 Fen Bilimleri Dersi Öğretim Programlarının Öğrenme Alanları Açısından Karşılaştırılması.}

Öğrenme alanları bağlamında 2013 ve 2018 öğretim programlarının karşılaştırılması sonucu elde edilen bulgular Tablo 2'de sunulmuştur.

Tablo 2

Öğretim Programlarının Öğrenme Alanları Açısından Karşılaştırılması

\begin{tabular}{|c|c|c|}
\hline Öğrenme Alanları & 2013 & 2018 \\
\hline \multirow{4}{*}{ Bilgi } & canlilar ve hayat & canlilar ve yaşam \\
\hline & madde ve değişim & madde ve doğası \\
\hline & fiziksel olaylar & fiziksel olaylar \\
\hline & dünya ve evren & dünya ve evren \\
\hline \multirow{3}{*}{ Beceri } & bilimsel süreç becerileri & bilimsel süreç becerileri \\
\hline & yaşam becerileri & yaşam becerileri \\
\hline & - & $\begin{array}{l}\text { mühendislik ve tasarım } \\
\text { becerileri }\end{array}$ \\
\hline \multirow{4}{*}{ Duyuş } & tutum & $V$ \\
\hline & motivasyon & - \\
\hline & değer & $V$ \\
\hline & sorumluluk & $\checkmark$ \\
\hline \multirow{6}{*}{ FTTÇ } & sosyobilimsel konular & $\checkmark$ \\
\hline & bilimin doğas1 & - \\
\hline & bilim ve teknoloji ilişkisi & $V$ \\
\hline & bilimin toplumsal katkısı & - \\
\hline & sürdürülebilir kalkınma & $\checkmark$ \\
\hline & fen ve kariyer bilinci & $\checkmark$ \\
\hline
\end{tabular}

Tablo 2'de, bilgi öğrenme alanında sadece ifade biçimlerinde değişikliğge gidildiği, beceri alanında ise bilimsel süreç ve yaşam becerilerine mühendislik ve tasarım becerilerinin eklendiği görülmektedir. 2013 öğretim programında açıkça ifade bulan duyuş ve FTTÇ öğrenme alanlarına bakıldığında, 2018 öğretim programında başlıklar halinde açıç̧a verilmemiş olmasına rağmen, programın bütününde bu öğrenme alanlarına ve bileşenlerine yönelik vurguların olduğu analiz sürecinde belirlenmiştir. 


\section{3 ve 2018 Fen Bilimleri Dersi Öğretim Programlarının Öğretmen-Öğrenci Rolü} Açısından Karşılaştırılması

2013 ve 2018 öğretim programlarında öğretmen-öğrenci rolleri genel itibariyle benzer şekilde ifade edilirken aynı zamanda 2013 öğretim programında ifade edilen rollerde, 2018 öğretim programında bazı ifade değişikliklerine gidilmiş veya eklemeler yapılmıştır. Öğretmen-öğrenci rollerine yönelik yapılan karşılaştırma verileri Tablo 3’te sunulmuştur.

Tablo 3

Öğretim Programların Öğretmen-Öğrenci Rolleri Açısından Karşılaştırılması

\begin{tabular}{|c|c|c|}
\hline & 2013 & 2018 \\
\hline \multirow{3}{*}{ 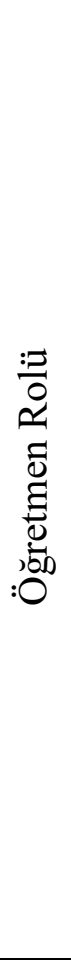 } & $\begin{array}{l}\text { Bilgiyi kendi zihninde yapılandırmaya } \\
\text { olanak tanıyan araştırma-sorgulamaya } \\
\text { dayalı öğrenme stratejisi benimsenir. }\end{array}$ & $\begin{array}{l}\text { Araştırma-sorgulama ve bilginin } \\
\text { transferine dayalı öğrenme stratejisi esas } \\
\text { alınmıştır. }\end{array}$ \\
\hline & $\begin{array}{l}\text { Kolaylaştırıcı ve yönlendirici rollerini } \\
\text { üstlenir, ..., kendi düşüncesini } \\
\text { öğrencisine kabul ettirme üzerine kurulu } \\
\text { öğretmen-öğrenci tartışmaları veya soru- } \\
\text { cevap-değerlendirme şeklindeki karşılıklı } \\
\text { konuşmalardan uzak durur, ... }\end{array}$ & $\begin{array}{l}\text { Teşvik edici ve yönlendirici rollerini } \\
\text { üstlenir, ..., kendi düşüncelerini ifade } \\
\text { etmesine, muhakeme ve iletişim } \\
\text { becerilerini geliştirmesine katkı } \\
\text { sağlayacaktır, ... }\end{array}$ \\
\hline & Karşılığ1 yok & $\begin{array}{l}\text { Bu süreçte, fen bilimlerinin matematik, } \\
\text { teknoloji ve mühendislikle } \\
\text { bütünleştirilmesi sağlanarak ögrrencilerin } \\
\text { problemlere disiplinler arası bakış } \\
\text { açıslyla bakması hedeflenir. Bu bağlamda } \\
\text { ögretmenlerin rolü ögrencilere fen, } \\
\text { teknoloji, mühendislik ve matematiğin } \\
\text { bütünleştirilmesi için rehberlik yaparak } \\
\text { ögrencileri üst düzey düşünme, ürün } \\
\text { geliştirme, buluş ve inovasyon yapabilme } \\
\text { seviyesine ulaştırmaktır. }\end{array}$ \\
\hline \multirow[b]{2}{*}{ 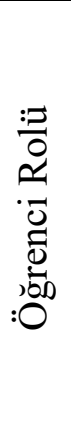 } & $\begin{array}{l}\text { Bilginin kaynağını araştıran, sorgulayan, } \\
\text { açıklayan ve tartışan birey rolünü } \\
\text { üstlenir. }\end{array}$ & $\begin{array}{l}\text { Bilginin kaynağını araştıran, sorgulayan, } \\
\text { açıklayan, tartışan ve ürüne dönüşsüren } \\
\text { birey rolünü üstlenir. }\end{array}$ \\
\hline & $\begin{array}{l}\text { Akranları ile birlikte bir bilgiyi araştırıp } \\
\text { sorgularken etkili iletişim ve işbirliği } \\
\text { gerçekleştirir. }\end{array}$ & $\begin{array}{l}\text { Akranları ile birlikte bir bilgiyi araştırıp } \\
\text { sorgularken etkili iletişim ve iş birliği } \\
\text { gerçekleştirir. Bu iş birliğinin ögrenme } \\
\text { ürünlerinin değerlendirilmesinde de } \\
\text { sağlanması, Program'ın amaçlarının } \\
\text { gerçekleştirilmesine katkı sağlayacaktır. }\end{array}$ \\
\hline
\end{tabular}

Tablo 3’ten görüldüğü gibi, her iki öğretim programında da öğrenme ve öğretme kuram ve uygulamaları açısından bütüncül bir bakış açısı benimsendiği, öğrencinin kendi öğrenmesinden sorumlu olduğu, öğrenme sürecine aktif katılımın sağlandığı ifade edilirken; 
2013 öğretim programında yer alan "bilgiyi kendi zihninde yapılandırmaya olanak tanıyan araştırma-sorgulamaya dayalı öğrenme stratejisi benimsenir” ifadesi 2018 öğretim programında “araştırma-sorgulama ve bilginin transferine dayalı öğrenme stratejisi esas alınmıştır" şeklinde değiştirilmiştir.

\section{3 ve 2018 Fen Bilimleri Dersi Öğretim Programlarının Benimsenen Strateji ve} Yöntemler Açısından Karşılaştırılması

Öğretim programlarının benimsenen strateji ve yöntemler açısından karşılaştırılması sonucu elde edilen bulgular Tablo 4’te sunulmuştur.

Tablo 4

Öğretim Programlarının Benimsenen Strateji ve Yöntemler Açısından Karşılaştırılması

\begin{tabular}{cl}
\hline \multicolumn{1}{c}{2013} & \multicolumn{1}{c}{2018} \\
\hline $\begin{array}{l}\text { Araştırma sorgulamaya dayalı öğrenme } \\
\text { yaklaşımı }\end{array}$ & $\begin{array}{l}\text { Disiplinler arası bir bakış açısıyla } \text { araştırma } \\
\text { sorgulamaya dayalı öğrenme yaklaşımı }\end{array}$ \\
\hline Keşfetme ve deney, açıklama ve argüman & $\begin{array}{l}\text { Keşfetme, sorgulama, argüman oluşturma } \\
\text { ve ürün tasarlama }\end{array}$ \\
\hline \multirow{2}{*}{ Karşılığı yok } & $\begin{array}{l}\text { Her bir ünitenin, konunun ve kazanımın } \\
\text { günlük hayat ihtiyaçlarını gidermeye yönelik } \\
\text { teknolojiler üretmesini gözeten bir yaklaşım }\end{array}$ \\
\hline \multirow{2}{*}{ Karşılığı yok } & $\begin{array}{l}\text { Öğrencilerin kendilerini yazıllı, sözlü ve } \\
\text { görsel olarak ifade ederek iletişim ve }\end{array}$ \\
& $\begin{array}{l}\text { yaratıcı düşünme becerilerinin } \\
\text { geliştirilmesine imkân tanıyan firsatların } \\
\text { öğrencilere sunulması }\end{array}$ \\
\hline
\end{tabular}

Tablo 4'ten görüldüğü gibi, iki öğretim programında da öğrencinin aktif olduğu, araştırma sorgulama süreçlerinde deneyerek ve keşfederek öğrenme imkânı bulduğu öğrenme ortamlarına vurgu yapılmaktadır. 2018 öğretim programında ayrıca, ürün tasarlama, günlük hayat ihtiyaçlarını gidermeye yönelik teknolojiler üretilmesi, iletişim ve yaratıcı düşünme becerilerinin geliştirilmesi gibi FeTeMM odaklı strateji ve yöntemlere odaklanılması gerektiği ifade edilmiştir.

2013 ve 2018 Fen Bilimleri Dersi Öğretim Programlarının Ölçme Değerlendirme Yaklaşımları Açısından Karşılaştırılması

Öğretim programlarında benimsenen ölçme değerlendirme yaklaşımlarının karşılaştırılması sonucu elde edilen bulgular Tablo 5'te sunulmuştur.

Tablo 5 
Öğretim Programlarında Benimsenen Ölçme Değerlendirme Yaklaşımlarının Karşılaştırılması

\begin{tabular}{|c|c|}
\hline 2013 & 2018 \\
\hline Karşılığ1 yok & $\begin{array}{l}\text { Ölçme ve değerlendirme uygulamalarının } \\
\text { bireysel farklılıklar da göz önünde } \\
\text { bulundurularak eş güdümlü ve birbirini } \\
\text { destekler nitelikte olmasl gerekmektedir. }\end{array}$ \\
\hline Karşılığ1 yok & $\begin{array}{l}\text { Ölçme ve değerlendirme sürecinin tanıma, } \\
\text { izleme ve sonuç odaklı olmak üzere üç } \\
\text { aşamada gerçekleştirilmesi gerekmektedir. }\end{array}$ \\
\hline Karşılığ1 yok & $\begin{array}{l}\text { Öğrencilerin kendi kendilerine yapacakları } \\
\text { öz değerlendirmeler, akran } \\
\text { değerlendirmeleri ve grup değerlendirmeleri } \\
\text { ile özgüvenlerinin ve öz denetimlerinin } \\
\text { artacă̆l ve ögrenmeyi ögrenmenin yollarını } \\
\text { açacaktır. }\end{array}$ \\
\hline Karşılığ 1 yok & $\begin{array}{l}\text { Ölçme değerlendirme uygulamalarında } \\
\text { bireysel farklılıkların göz önünde } \\
\text { bulundurulmasl gerekmektedir. }\end{array}$ \\
\hline
\end{tabular}

Tablo 5’te, 2018 öğretim programında benimsenen ölçme değerlendirme yaklaşımı 2013 öğretim programından büyük ölçüde farklılık gösterdiği tespit edilmiştir. 2018 öğretim programında özellikle bireysel farklılıkların ön plana çıkarıldığı ve bu doğrultuda ölçme ve değerlendirmelerin belirli aşamalar çerçevesinde, öz değerlendirme, akran değerlendirme gibi değerlendirme türlerinin de sürece dahil ederek yapılması gerektiği ifade edilmektedir.

\section{3 ve 2018 Fen Bilimleri Dersi Öğretim Programlarının Bilgi Öğrenme Alanlarında Yapılan Değişiklikler}

2013 ve 2018 Fen Bilimleri Dersi Öğretim Programlarında yer alan bilgi öğrenme alanları ve bu alanların içerdiği kazanım sayısı ve ders saati ile ilgili bulgulara bu bölümde yer verilmiştir.

\section{Bilgi Öğrenme Alanlarının Kazanım Sayısı ve Ders Saatindeki Değişim}

2013 ve 2018 programlarında yer alan kazanım sayısı ve ders saatleri, her bir öğrenme alanı çerçevesinde Tablo 6'da verilmiştir.

Tablo 6

2013 ve 2018 programlarında yer alan kazanım sayısı ve ders saati

\begin{tabular}{|c|c|c|c|c|c|c|c|c|c|c|c|c|c|c|c|}
\hline & & \multicolumn{2}{|c|}{ 3. sinif } & \multicolumn{2}{|c|}{ 4. sinif } & \multicolumn{2}{|c|}{ 5. sinif } & \multicolumn{2}{|c|}{ 6. sinif } & \multicolumn{2}{|c|}{ 7. sinif } & \multicolumn{2}{|c|}{ 8. sinif } & \multicolumn{2}{|c|}{ Toplam } \\
\hline & & k.s. & d.s. & k.s. & d.s. & k.s. & d.s. & k.s. & d.s. & k.s. & d.s. & k.s. & d.s. & k.s. & d.s. \\
\hline 2013 & $\begin{array}{l}\text { Dünya ve } \\
\text { Evren }\end{array}$ & 3 & 9 & 1 & 9 & 10 & 24 & 4 & 16 & 9 & 16 & 16 & 18 & 43 & 92 \\
\hline
\end{tabular}




\begin{tabular}{cccccccccccccccc}
\hline 2018 & $\begin{array}{c}\text { Dünya ve } \\
\text { Evren }\end{array}$ & 5 & 9 & 5 & 15 & 7 & 24 & 5 & 14 & 10 & 16 & 3 & 14 & 35 & 92 \\
\hline 2013 & $\begin{array}{c}\text { Canlılar ve } \\
\text { Hayat }\end{array}$ & 9 & 27 & 15 & 30 & 16 & 48 & 18 & 48 & 20 & 38 & 24 & 40 & $\begin{array}{c}10 \\
2\end{array}$ & $\begin{array}{c}23 \\
1\end{array}$ \\
\hline \multirow{2}{*}{2018} & $\begin{array}{c}\text { Canlılar ve } \\
\text { Yaşam }\end{array}$ & 11 & 24 & 8 & 24 & 9 & 32 & 22 & 42 & 15 & 34 & 25 & 46 & 90 & $\begin{array}{c}20 \\
2\end{array}$ \\
\hline \multirow{2}{*}{2013} & $\begin{array}{c}\text { Fiziksel } \\
\text { Olaylar }\end{array}$ & 16 & 57 & 19 & 42 & 12 & 52 & 16 & 44 & 27 & 60 & 15 & 56 & $\begin{array}{c}10 \\
5\end{array}$ & $\begin{array}{c}31 \\
1\end{array}$ \\
\hline \multirow{2}{*}{2018} & $\begin{array}{c}\text { Fiziksel } \\
\text { Olaylar }\end{array}$ & 16 & 58 & 20 & 39 & 14 & 50 & 19 & 48 & 26 & 54 & 16 & 44 & $\begin{array}{c}11 \\
1\end{array}$ & $\begin{array}{c}29 \\
3\end{array}$ \\
\hline \multirow{2}{*}{2013} & $\begin{array}{c}\text { Madde ve } \\
\text { Değişim }\end{array}$ & 4 & 15 & 11 & 27 & 6 & 20 & 14 & 36 & 22 & 30 & 23 & 40 & 80 & $\begin{array}{c}16 \\
8\end{array}$ \\
\hline \multirow{2}{*}{2018} & $\begin{array}{c}\text { Madde ve } \\
\text { Doğası }\end{array}$ & 4 & 17 & 10 & 21 & 6 & 26 & 13 & 28 & 16 & 28 & 17 & 28 & 66 & $\begin{array}{c}14 \\
8\end{array}$ \\
\hline \multirow{2}{*}{ Toplam } & FeTeMM & - & - & - & 9 & - & 12 & - & 12 & - & 12 & - & 12 & - & 57 \\
\hline & 2013 & 32 & $\begin{array}{c}10 \\
8\end{array}$ & 46 & $\begin{array}{c}10 \\
8\end{array}$ & 44 & $\begin{array}{c}14 \\
4\end{array}$ & 52 & $\begin{array}{c}14 \\
4\end{array}$ & 78 & $\begin{array}{c}14 \\
4\end{array}$ & 78 & $\begin{array}{c}14 \\
4\end{array}$ & $\begin{array}{c}33 \\
0\end{array}$ & $\begin{array}{c}79 \\
2\end{array}$ \\
\hline
\end{tabular}

* k.s. : kazanım sayısı, d.s. : ders saati

Tablo 6’da görüldüğü üzere 2013 programında toplam 330 kazanım yer alırken, 2018 programında bu sayı 302'ye düşmüştür. Bu kazanımlar için verilen ders saati sürelerinde ise bir değişiklik olmamıştır. Genel anlamda bakıldığında, öğrenme alanlarında yer alan kazanım sayılarında büyük ölçüde azalma olduğu görülmektedir. Bununla birlikte, Fiziksel Olaylar öğrenme alanında, kazanım sayısı artarken ders saatlerinde azalma olduğu belirlenmiştir. Bunların yanı sıra, 2018 öğretim programında görülen en büyük değişikliğin programa FeTeMM öğrenme alanının eklenmesi olarak görülmektedir.

\section{Bilgi Öğrenme Alanlarının İçeriğindeki Değişim}

Bu bölümde 2013 ve 2018 programlarında yer alan bilgi öğrenme alanları, "kazanım ifadelerindeki değişim”, "eklenen ve çıkarılan kazanımlar" ve "konuların sıralaması ve sınıf düzeyleri arasındaki değişim” alt başlıkları bağlamında yapılan değişiklikler açısından ele alınmıştır.

\section{Dünya ve Evren Öğrenme Alanı}

Dünya ve Evren bilgi öğrenme alanında yer alan kazanımlara, kazanım ifadelerindeki değişim bağlamında bakıldığında, üçüncü sınıf "dünyanın şekli” ünitesinde yer alan “Dünya'nın şeklinin küreye benzediğini ifade eder" kazanımının fiili "farkına varır" ş̧eklinde, “... etrafımızı saran bir hava tabakasının bulunduğunu kavrar" kazanımının fiili ise "açıklar” şeklinde değiştirilmiştir. Dördüncü sınıf düzeyinde yer alan "dünyanın dönme ve dolanma hareketlerini açıklar" kazanımının fiili bu iki hareket arasındaki "farkı açıklar" biçiminde 
güncellenmiştir. Beşinci sınıf “yer kabuğunda neler var?” ünitesindeki “yer kabuğunun kara tabakasının kayaçlardan oluştuğunu bilir" kazanımının fiili “belirtir" şeklinde ifade edilmiştir. Benzer şekilde, sekizinci sınıf "iklim” ünitesinde yer alan "iklim bilimin (klimatoloji) bir bilim dalı olduğunu ve bu alanda çalışan uzmanlara iklim bilimci (klimatolog) adı verildiğini bilir" kazanımının fiili “söyler” şeklinde değiştirilmiştir. 2018 öğretim programı incelendiğinde, 2013 öğretim programında birden fazla amaç içeren kazanımlardan bazılarının bölünerek ayrı birer kazanım olarak ifade edildiği görülmektedir. Örneğin; üçüncü sınıf düzeyinde yer alan “dünya yüzeyinde karaların ve suların yer aldığını ve etrafimızı saran bir hava tabakasının bulunduğunu kavrar" kazanımı, "dünyanın yüzeyinde karaların ve suların yer aldığını kavrar” ve "dünyada etrafımızı saran bir hava katmanının bulunduğunu açıklar" şeklinde ifade edilmiştir.

Eklenen ve çıkarılan kazanımlar bağlamında incelendiğinde ise, eklenen kazanımlara örnek olarak, üçüncü sınıf düzeyinde "dünyanın şekliyle ilgili model hazırlar”, "uzay teknolojilerini açıklar”, "basit bir teleskop modeli hazırlayarak sunar” kazanımlarının eklendiği görülürken, "yıldız oluşum sürecinin farkına varır”, "yıldız kavramını açıklar”, "galaksilerin yapısını açıklar" ve "evren kavramını açıklar” kazanımlarını içeren yeni bir konu başlığının programa eklendiği belirlenmiştir. Beşinci sınıf düzeyinde "güneşin yapısı ve özellikleri”, “ayın yapısı ve özellikleri” ve "güneş, dünya ve ay" konuları, altıncı sınıf düzeyinde "güneş ve ay tutulmaları" konusu, yedinci sınıf düzeyinde "güneş sistemi ve ötesi: gök cisimleri” konusu yeni kazanımlar ile birlikte programa dahil edilmiştir. Öğretim programından çıkarılan kazanımlara, beşinci sınıf “yer kabuğunda neler var?” ünitesinde yer alan “fosil bilimin, bir bilim dalı olduğunu kavrar ve bu alanda çalışan uzmanlara ne ad verildiğini bilir”, "doğal anıtlara örnekler verir ve kültürel miras olarak önemini tartışı” ve “doğal anıtların korunarak gelecek nesillere aktarılmasına yönelik öneriler sunar” kazanımlarının çıkarılması örnek verilebilir.

Konuların sıralaması ve sınıf düzeyleri arasındaki değişim bağlamında incelendiğinde, tüm sınıf düzeylerinde son konu olarak verilen Dünya ve Evren öğrenme alanındaki konuların her sınıf düzeyinde ilk konu olarak ele alındığı görülmektedir. Bunun yanı sıra, konuların yer aldığı sınıf düzeylerinde yapılan değişikliklere bakıldığında, beşinci sınıf düzeyinde yer alan “yer kabuğunda neler var?” konusu dördüncü sınıfa alınarak, ismi "yer kabuğunun yapısı" şeklinde değiştirilmiştir. Yedinci sınıf düzeyinde yer alan "güneş sistemi” konusu ise altıncı sınıf düzeyine çekilmiştir. 


\section{Canlılar ve Yaşam Ö̆̆renme Alanı}

Kazanım ifadelerindeki değişimler bağlamında incelendiğinde, üçüncü sınıf düzeyinde "beş duyumuz" konu başlığı altında yer alan "duyu organlarını tanır" kazanımının "duyu organlarının önemini fark eder" ş̧eklinde değiştirildiği görülürken, "duyu organlarının să̆lı̆̆ını korumak için yapılması gerekenleri kavrar" kazanımının fiilinin "açıklar” şeklinde güncellendiği belirlenmiştir. Sekizinci sınıf düzeyindeki "insanda üreme, büyüme ve gelişme" konusunda yer alan "sperm, yumurta, zigot, embriyo, fetüs ve bebek arasındaki ilişkiyi yorumlar" kazanımının fiili "açıklar" şeklinde değiştirilmiştir.

Eklenen ve çıkarılan kazanımlar bağlamında bakıldığında, eklenen kazanımlar için örnek olarak, üçüncü sınıf düzeyindeki "çevremizdeki varlıkları tanıyalım” konusuna eklenen "bir bitkinin yaşam döngüsüne ait gözlem sonuçlarını sunar" kazanımı verilebilir. Benzer şekilde, beşinci sınıf düzeyinde "biyoçeşitlilik" konusuna "insan faaliyetleri sonucunda gelecekte oluşabilecek çevre sorunlarına yönelik çıkarımda bulunur", altıncı sınıf düzeyinde "sistemlerin sağlığı" konusuna "sistemlerin sağlı̆̆ için yapılması gerekenleri araştırma verilerine dayalı olarak tartışır", sekizinci sınıf düzeyinde ise "kalıtım" konusuna "tek karakter çaprazlamaları ile ilgili problemler çözerek sonuçlar hakkında yorum yapar" kazanımlarının eklendiği belirlenmiştir. Öğretim programından çıkarılan kazanımlar incelendiğinde, dördüncü sınıf düzeyinde "vücudumuzun bilmecesini çözelim” konusundan “vücudumuzun destek ve hareketini sağlayan kemik, eklem, kas ve iskelet kavramlarını ve bu yapılar arasındaki ilişkileri açıklar" ve beşinci sınıf düzeyinde "besinlerin sindirimi”" konusunda "diş çeşitlerini model üzerinde göstererek görevlerini açıklar" kazanımlarının çıkarıldı̆̆ı tespit edilmiştir.

Konuların sıralaması ve sınıf düzeyleri arasındaki değişim bağlamında bakıldığında, yedinci sınıf düzeyinde yer alan "vücudumuzdaki sistemler" ünitesinin altıncı sınıf düzeyine çekildiği görülmüştür. Altıncı sınıf düzeyindeki "bitki ve hayvanlarda üreme, büyüme ve gelişme” ve sekizinci sınıftaki “insanda üreme, büyüme ve gelişme” ünitelerinin yedinci sınıf düzeyinde "canlılarda üreme, büyüme ve gelişme" ünitesi altında konu başlıkları olarak yer aldığı belirlenmiştir.

\section{Fiziksel Olaylar Ö̆̆renme Alanı}

Kazanım ifadelerindeki değişimler bağlamında bakıldığında, bazı kazanımların ifadelerinin daha üst bilişsel seviyeye taşındığı belirlenirken bazı kazanımların ifadelerinde sadeleştirmeye gidilerek daha alt düzeydeki bilişsel seviyelere çekildiği görülmüştür. Dördüncü sınıf "kuvvetin etkileri" konusunda yer alan "mıknatısın ne olduğunu ve kutuplarını bilir" 
kazanımının fiili “keşfeder" şeklinde değiştirilmiştir. Yine dördüncü sınıf düzeyinde yer alan "basit elektrik devresini oluşturan devre elemanlarını işlevleriyle tanır ve çalışan bir devre kurar" kazanımı 2018 öğretim programında "basit elektrik devresini oluşturan devre elemanlarını işlevleriyle tanır" ve "çalışan bir elektrik devresi kurar" şeklinde iki ayrı kazanım olarak ifade edilmiştir. Yedinci sınıf düzeyinde "kuvvet, iş ve enerji ilişkisi”" konusunda yer alan "fiziksel anlamda yapılan işin uygulanan kuvvet ve alınan yolla doğru orantılı olduğunu kavrar ve birimini belirtir" kazanımının ikinci kısmı açıklama maddesine dönüştürülürken, birinci kısmının fiili “açıklar" şeklinde değiştirilmiştir. Diğer yandan, yedinci sınıf "elektrik enerjisi” konusunda yer alan "elektrik enerjisinin hareket enerjisine, hareket enerjisinin de elektrik enerjisine dönüştüğünü kavrar" kazanımı yeni öğretim programının FeTeMM odaklı hazırlanmasına paralel olarak "elektrik enerjisinin ısı, ışık veya hareket enerjisine dönüşümünü temel alan bir model tasarlar" şeklinde değiştirilmiştir.

Eklenen ve çıkarılan kazanımlar bağlamında incelendiğinde, sekizinci sınıfa taşınan "basınç” konusuna "açık hava basıncı" kavramının ve bu kavramın kazanımlarının eklendiği belirlenmiştir. Ayrıca eklenen kazanımlara beşinci sınıf düzeyinde "kuvvetin ölçülmesi ve sürtünme” ünitesinde "basit araç gereçler kullanarak bir dinamometre modeli tasarlar" ve "günlük yaşamda sürtünmeyi artırma veya azaltmaya yönelik yeni fikirler üretir"; yedinci sinıf düzeyinde "kuvvet ve enerji” ünitesinde "yer çekimini kütle çekimi olarak gök cisimleri temelinde açıklar" ve "özgün bir aydınlatma aracı tasarlar" kazanımları örnek olarak verilebilir. Yedinci sınıf düzeyinde yer alan "elektrik enerjisi” ünitesindeki elektrik devreleri konusunun içinde yer alan "ampermetre", "voltmetre” ve “ohm yasası" kavramlarının 2018 öğretim programında herhangi bir sınıf düzeyinde ifade edilmediği belirlenmiştir. Ayrıca aynı ünitede yer alan “ampullerin seri ve paralel bă̆landı̆̆ durumlardaki parlaklık farklılı̆̆ının sebebini elektriksel dirençle ilişkilendirir" kazanımı yenilenen programda yer almamaktadır.

Konuların sıralaması ve sınıf düzeyleri arasındaki değişim bağlamında incelendiğinde, yedinci sınıf "kuvvet ve enerji” konusunda yer alan "katı basıncını etkileyen değişkenleri deneyerek keşfeder ve bu değişkenler arasındaki ilişkiyi analiz eder" kazanımı, sekizinci sınıf "basınç” konusunda "katı basıncını etkileyen değişkenleri deneyerek keşfeder" olarak ifade edilmiştir. Benzer şekilde, yedinci sınıf düzeyindeki “elektrik enerjisi” ünitesinde yer alan “elektrik enerjisinin dönüşümü” konusu sekizinci sınıf “elektrik yükleri ve elektrik enerjisi” ünitesinin altında ifade edilmiştir. Yedinci sınıf düzeyinde "kuvvet ve enerji” ünitesinin içinde yer alan "basınç” konusu sekizinci sınıfa ünite olarak taşınmıştır. Beşinci ve altıncı sınıf 
düzeylerinde bir ünite başlığı altında verilen “1şık ve ses” kavramları, beşinci sınıf düzeyinde sadece "ses" kavramına, altıncı sınıf düzeyinde ise sadece "1şık" kavramına yönelik kazanımların yer aldığı ünite başlıkları şeklinde düzenlenmiştir.

\section{Madde ve Dŏgası Ö̆̆renme Alanı}

Kazanım ifadelerindeki değişimler bağlamında bakıldığında, üçüncü sınıf düzeyinde "maddeyi tanıyalım” konusunda yer alan "bazı maddelere dokunma, onlar tatma ve koklamanın canlı vücuduna zarar verebileceğini fark eder" kazanımının fiilinin "tartışır" şeklinde değiştirildiği belirlenmiştir. Dördüncü sınıf düzeyinde "maddelerin ısı etkisiyle hal değiştirebileceğine yönelik deney yapar ve sonuçları yorumlar" kazanımındaki "deney yapar ve sonuçları yorumlar" ifadesi "deney tasarlar" biçiminde güncellenmiştir. Altıncı sınıf düzeyinde "madde ve 1sı” ünitesindeki “hal değişimine bağll olarak maddenin tanecikleri arasındaki boşluk ve taneciklerin hareketliliğinin değiştiğini kavrar” kazanımının fiili “deney yaparak keşfeder" şeklinde değiştirilmiştir. Yine altıncı sınıf düzeyinde aynı konu başlığı altında "farklı türdeki yakıtların ısı amaçlı kullanımının, insan ve çevre üzerine etkilerini araştırır ve sunar" kazanımının fiili "tartışır" şeklinde güncellenmiştir. Yedinci sınıf düzeyindeki “evsel atıklar ve geri dönüşüm” konusundaki "geri dönüşüm tesislerinin ekonomiye katkısını tartışı»" kazanımının fiilinin "vurgulanır" şeklinde düzenlenerek öğrencinin tartışması yerine öğretmen tarafından vurgulanması beklenen bir yapıya çekildiği, aynı zamanda bir kazanım maddesi olmaktan çıkarılarak "geri dönüşümü, kaynakların etkili kullanımı açısından sorgular" kazanımının açıklaması olarak yeni programda yer aldığı görülmüştür.

Eklenen ve çıkarılan kazanımlar bağlamında bakıldığında, dördüncü sınıf düzeyindeki "maddenin 1sı etkisi ile değişimi” konusunda yer alan "erime ve donma" kavramlarına ek olarak “buharlaşma" kavramının eklendiği belirlenmiştir. Altıncı sınıf düzeyinde "yakıtlar” konusu altında yer alan kazanımlar genel anlamda değiştirilmezken, sadece kazanım açıklamasında ifade edilen "yenilenebilir ve yenilenemez enerji kaynakları" kavramlarının, ilgili konunun temel kavramları arasında ifade edildiği belirlenmiştir. Çıkarılan kazanımlara bakıldığında, yedinci sınıf düzeyinde “evsel atıklar ve geri dönüşüm” konusundaki “atık suların arıtımına yönelik model oluşturur ve sunar" kazanımının ve "kimya endüstrisi” konusunun güncel öğretim programında yer almadığı belirlenmiştir.

Konuların sıralaması ve sınıf düzeyleri arasındaki değişim bağlamında incelendiğinde, altıncı sınıf düzeyinde iki ayrı ünite olarak verilen "maddenin tanecikli yapısı" ve "madde ve 
1sı” ünitelerinin “madde ve 1sı” ünite başlığı altında toplandığı görülmüştür. Altıncı sınıf düzeyinde “fiziksel ve kimyasal değişmeler” konu başlığı ile verilen kazanımın, sekizinci sınıf düzeyine taşındığı ve “madde ve endüstri” ünitesi altında ikinci konu başlığı olarak düzenlendiği görülmüştür.

\section{Tartışma}

2013 ve 2018 Fen Bilimleri Dersi Öğretim Programlarının, genel eğilimler ve yaklaşımlar açısından karşılaştırılmasının amaçlandığı bu çalışmada, dersin temel amacında herhangi bir değişikliğe gidilmediği görülmüştür. İki programda da temel amaç olarak ele alınan "fen okuryazarı birey yetiştirmek" fen eğitiminin en temel amacıdır (MEB, 2018; Rutherford ve Ahlgren, 1990).

Her iki programda da yer verilen alt amaçlarda değişikliklere gidilmiş, bazı amaçların içeriği yapısı bozulmayacak şekilde ve basit düzeyde değiştirilirken, bazıları kaldırılmış ve yeni bir alt amaç programa eklemiştir. Eklenen alt amaçta temel vurgu değerler eğitimi üzerine yapılandırılmış ve bilimsel etik ilk defa bu alt amaç ile kendisine programda yer bulmuştur. Eğitim sistemimizde daha öncesinde örtük amaç olarak kendisine yer bulan değerler eğitiminin, tüm programlarda temel alt amaçlara eklenmesi, bireylerin hem davranış hem de öğrenmesi üzerinde etkisi olan (Çengelci, Hancı ve Karaduman, 2013) ve öğrencilerin karakter, benlik ve ahlaki gelişimleri için okulun kazandırması gereken (Akbaş, 2007) değerler açısından önemli bir adım olarak değerlendirilebilir. Kaldırılan alt amaçlar incelendiğinde, bilimin toplum ve teknoloji ile olan ilişkisinin ve bilimsel çalışmaların genel çerçevesinin öğrencilere kazandırılmasının amaçlandığı görülmektedir. Bilimin, toplum için önemi, özellikle bireylerin karar verme ve problem çözme süreçlerinde önemli rol oynaması (Aikenhead, 2006; Çalık ve Coll, 2012; Gauld, 1982) göz önüne alındığında, öğrencilerin bilim ve bilimsel süreçlerle en yoğun ilgilendikleri ders olan fen bilimleri dersinden bu amaçların kaldırılması, öğrencilerin ilerleyen yaşantılarında özellikle toplumsal mesele ve problemlerin çözümü ve karar verme süreçlerinde sorun yaşayabilme endişesi ve ihtimalini ortaya çıkarmaktadır. Ancak bu endişe, FeTeMM eğitimi ile problem çözme ve bilimsel süreçlerin öğrencilere kazandırılması ile bir nebze de olsa giderilebilecektir.

Önceki program ile karşılaştırıldığında göze çarpan en önemli değişikliklerin başında, FeTeMM eğitiminin 2018 programında hem temel amaçlara hem de öğrenci ve öğretmen rolüne eklenmesi gelmektedir. Kendisine temel amaçlarda yer bulan FeTeMM eğitimi, aynı zamanda 
öğretmen rolüne de eklenmiş ve öğretmenin ilgili alanların öğrenci tarafından birleştirilmesi ve bu alanın gerekliliklerinin öğrenciler tarafından sahip olunması için rehber olması gerektiği vurgulanmıştır. FeTeMM Eğitimi Türkiye Raporu (Akgündüz ve diğ, 2015), bu alanda eğitim politika ve programlarının geliştirilmesine ihtiyaç olduğunu göstermektedir. Bu anlamda 2018 programının FeTeMM eğitimine yönelik ihtiyaçlardan önemli birisini giderdiği düşünülebilir. Ancak, Fen Bilimleri öğretmenlerinin zaman ve malzeme eksikliğinin başta geldiği sorunlardan dolayı FeTeMM eğitimini tam anlamıyla gerçekleştiremedikleri (Eroğlu ve Bektaş, 2016), fen bilimleri öğretmenlerinin FeTeMM ile ilgili bilgilerinin yeterli olmadığı (Bakırcı ve Kutlu, 2018), eğitim fakültelerinde bu alanda yeterli seviyede kuramsal hazırlık ve uygulama yapılmadığı (Çolakoğlu ve Günay-Gökben, 2017), öğretmen eğitiminde direkt olarak bu alanla ilgili bir dersin bulunmaması nedeniyle bu alanın öğretmen eğitimine daha fazla ve daha etkili bir şekilde entegre edilmesi gerekliliği (Akaygün ve Aslan-Tutak, 2016; Aslan-Tutak, Akaygün ve Tezsezen, 2017; Yılmaz ve Pekbay, 2017) gibi sorunların olduğu söylenebilir. Tüm bu eksiklikler düşünüldüğünde, geliştirilen programlarda kendine yer bulan FeTeMM eğitiminde, öğretmenin üzerine düşen rolü ne derece gerçekleştirebileceği sorusu ortaya çıkmaktadır. Her ne kadar 2018 yılında güncellenen Fen Bilgisi Öğretmenliği lisans programına "Disiplinlerarası Fen Öğretimi” ile FeTeMM eğitimi eklenmiş olsa da (YÖK, 2018), hali hazırda görev yapmakta olan öğretmenlerin birçoğunun, özellikle meslekte 10-15 ve daha fazla yıl geçirmiş olanların lisans eğitimleri boyunca bu konu hakkında herhangi bir ders almadıkları düşünüldüğünde, FeTeMM ile ilgili kazanımlar konusunda yetersiz kalabilecekleri düşünülmektedir. Her ne kadar hizmet içi eğitim ve seminerler ile öğretmenlere bu yeni konu hakkında eğitimler verilse de özellikle 2004 programı ile getirilen öğretmen kılavuz kitabı gibi bir kitabın olmaması, kazanımların öğretmenler tarafından tam olarak anlaşılması konusunda yeni programın bir eksikliği olarak nitelendirilebilir (Bahar ve diğ., 2018).

2018 programında yapılan en önemli değişiklerin başında gelen FeTeMM eğitiminin programa dâhil edilmesi, yalnızca genel amaç, öğretmen ve öğrenci rolüne eklenmesiyle değil, aynı zamanda kazanım ifadelerinde yapılan değişiklikler ve eklenen konu alanları ile de kendisini göstermektedir. İfadelerde yapılan değişiklikler incelendiğinde, tasarım yapma ve fikir üretme gibi FeTeMM eğitimi ile doğrudan ilgili ifadelerin kazanımlara eklendiği görülmektedir. Bu ifadelerin yer aldığı kazanımlar FeTeMM eğitimi için önem arz etmektedir. Aynı zamanda, bu kazanımlar çerçevesinde ortaya konulan model, tasarım gibi ürünlerin üçüncü sınıf hariç, diğer sınıfların son konusu olarak eklenen yıl sonu bilim şenliği ile 
pekiştirilmesinin, öğrencilerin FeTeMM ile ilgili bilgi, motivasyon ve tutumlarını geliştireceği düşünülmektedir (Bahar ve diğ., 2018).

2018 öğretim programında yapılan değişikliklerden bazılarının öğrencilerin aktif olarak öğrenmelerini hedeflediği görülmektedir. Bu bağlamda, yapılan düzenlemelerin öğrencilerin araştırma yapmaya teşvik edilmesini sağlamak adına faydalı olacağı görülmüştür. Diğer yandan, kazanımlardaki ifade değişimlerine bakıldığında, örneğin, fark etme eylemi gözlemlerini ifade etmesini içerirken, tartışır ifadesinin getirildiği kazanımlarda, gözlemlerinden yola çıkarak sorgulayıcı bir bakış açısıyla fikir üretmesini ve fikirlerini başkalarıyla paylaşma, farklı fikirleri dinleme ve kendi fikirlerini savunma süreçlerini içerdiğinden, öğrencilerin zihinsel olarak daha aktif olabilecekleri bir öğrenme ortamına işaret ettikleri görülmektedir. $\mathrm{Bu}$ tür değişiklikler öğrencilerin üst bilişsel becerilerinin geliştirilmesine katkı sağlayacaktır. Nitekim, Millî Eğitim Bakanlığı tarafından yapılan çalışmada, öğrencilerin üst bilişsel becerilerinin gelişiminin desteklenmesine vurgu yapılmıştır (Bakırcı ve Kutlu, 2018). Bu bağlamda, bakanlık tarafindan belirlenen bu ihtiyacın, yeni Fen Bilimleri programında kendisine yer bulduğu görülmektedir. Bunun yanı sıra, üst bilişsel becerilerin kullandırılması ve kendi araştırmaları sonucu bilgiye ulaşmaları ve kendi kendine öğrenmelerinin teşvik edilmesi ile, öğrenciler kavrama düzeyinde kalmak yerine var olan durumu deneyimleyerek keşfetme imkânı bulacaklardır. Bu durum öğrencilerin anlamlı öğrenmelerini destekleyecek nitelik taşımaktadır.

Analiz sonucunda bazı kazanımların eski programa kıyasla daha yüzeysel ve net olmayan ifadelerle sunulduğu, bazı kazanımlar için ayrılan sürenin de kısaltıldığı görülmüştür. Bu tür değişiklikler kuşkusuz öğretmenlerin öğretim sürecinde yapılan deneyleri sonuçlandırmayacakları ya da derinlemesine öğrenmelerin gerçekleştirilmeyeceği anlamına gelmemekle birlikte, ifadelerin açık ve net biçimde yazılmasının özellikle mesleğe yeni başlayan öğretmenler için bir ihtiyaç olduğu düşünülmektedir. Ayrıca 2004 Fen Bilgisi Öğretim Programı ile getirilen öğretmen kılavuz kitabı gibi, programın uygulanmasında öğretmenlere yardımcı olacak bir kaynağın olmaması, bu problemin giderilmesi konusunda bir eksiklik olarak nitelendirilebilir.

Özellikle bilimsel bilgi üretimi ya da teknolojik gelişmelerin olduğu kazanımlara yönelik olarak yapılan değişikliklerde, kazanımlara açıklama olarak tarihsel gelişim süreçlerinde detay verilmemesi ya da kronolojik sıralamalar yapılmaması beklendiği ifade edilmiştir. Öğrencilerin bilimsel gelişmelerin farkında olmalarının, teknolojik gelişmeleri takip edebilen ve bunların 
tarihsel süreçteki gelişimlerinin farkında olan bireyler olarak yetiştirilebilmesi için bilim tarihi vurgusunun öğrenme ortamlarında yer almasının önemli olduğu düşünülmektedir (Kıryak, Candaş ve Ünal, 2018; Yıldırım, 2012). Yapılan çalışmalar, bilime karşı olumlu tutum geliştirmek (Heering, 2000; Koştur, 2017; Kubli, 1999; Lederman, 1998) ve öğrencilerin bilimsel süreç becerilerini geliştirmek (Dedes ve Ravanis, 2008; Kolstø, 2008) için fen eğitiminde kullanılması gereken önemli araçlardan birisinin de bilim tarihi olduğunu göstermektedir. Öğrencilerin tarihsel gelişim süreçlerinden haberdar edilmemesinin bilimin tarihsel gelişimi ve bilimin doğası unsurlarının yardımı ile sağlanacak katkıyı ortadan kaldıracak nitelikte bir değişim olduğu söylenebilir. Bilim tarihinin çıkarılması öğrencilerin 21. yüzyılın getirdiği problemlerin çözümünde başarılı olma ihtimalini azaltacaktır (National Research Council [NRC], 2005). Aynı zamanda, öğrencilerin geleceğe 1şık tutacak tasarımlar yapmalarına yönelik beklentilerin hayata geçirilebilmesinin, teknolojinin tarihsel gelişim süreçlerine yönelik bilişsel ve duyuşsal anlamda farkındalığın kazandırılması ile mümkün olduğuna inanılmaktadır.

Bazı kazanımlarda modern ve kültürel boyutlarda somut örneklerin incelenmesine yönelik vurgu yapıldığı belirlenmiştir. Bu noktada, öğrencilerin tarihsel süreçte kültürel değerlerin ve o dönemdeki koşullar altında ne kadar gelişmiş tasarımlar yapılabildiğini görmelerinin onların kültürel değerlere bağlılığının artması ve dönemin bilim insanlarını örnek alarak kariyer bilinci geliştirmeleri adına oldukça etkili sonuçlar vereceği düşünülmektedir. Bu şekilde, öğrencilerin sahip oldukları bilgileri kullanarak tasarımlar yapmalarının, 21. yüzyıl becerileri kapsamında ifade edilen yaratıcılık becerilerinin geliştirilmesine imkân verebileceği de düşünülmektedir. Bu bağlamda, doğru bir rehberlik ile öğrencilerin farklı alanlara yönelik bilgi ve becerilerini birleştirerek tasarım yapmaları desteklendiğinde FeTeMM uygulamalarına yönelik etkili çalışmaların yürütülebileceği düşünülmektedir. Bunun yanı sıra, bazı kazanımların öğrencilerden bir ürün tasarımı yapmalarını istemese de geleceğe yönelik öngörülerini, sahip oldukları bilgiler çerçevesinde yorumlamalarını ve tartışma ortamında savunmalarını gerektirdiği görülmektedir. Bu tür kazanımların da öğrencilerin yaratıcılıklarının ve eleştirel düşünme becerilerinin geliştirilmesi adına faydalı sonuçlar elde etmeye imkân verecek nitelikte olduğu düşünülmektedir. $\mathrm{Bu}$ paralelde, öğrencilerin ulaştıkları bilgileri sunmanın ötesinde bilgiyi anlama, yorumlama, eleştirel bir bakış açısıyla değerlendirerek tartışma imkânı bulacak olmalarının ve bilim insanlarını örnek almalarının hem kavramsal öğrenme hem de fikirlerini ifade etme ve savunma firsatı bulmanın yanı sıra sorgulayıcı ve 
eleştirel düşünme becerileri ile bilimsel düşünme alışkanlıklarının gelişmesini destekleyeceği düşünülmektedir.

Bazı konu başlıklarının ve kazanımların sınıf seviyeleri arasında yer değiştirdiği ve bazılarının da ayrılarak diğer sınıf seviyelerine dağıtıldığı belirlenmiştir. Yer değiştirmelere bakıldığında, bu değişikliklerin büyük kısmının üst sınıf düzeyinden bir ya da iki kademe alt düzeye taşındığı belirlenmiştir. Örneğin, “sesin sürati, ışı̆̆ıı kırılması ve mercekler” kavramları 2013 öğretim programında sekizinci sınıf düzeyindeyken yeni öğretim programında bu ünitenin tamamının diğer sınıf düzeylerine aktarıldığı belirlenmiştir. Bu üniteye ait kavramların düşük sınıf düzeylerindeki öğrenciler için sekizinci sınıf düzeyindeki öğrencilere kıyasla daha soyut ve anlaşılması zor kavramlar olabileceği, dolayısıyla kavramsal düzeyde anlama ve öğrenmede zorluk yaşayabilecekleri düşünülmektedir. $\mathrm{Bu}$ konulardan 1şı konusuyla ilgili yapılan çalışmalar, öğrencilerin bu konu ile ilgili sorun yaşadıklarını ve bu sorunun konunun soyut olmasından kaynaklandığını göstermektedir (Bakırcı, Çepni ve Yıldız, 2015; Demirci ve Ahçı, 2016; Evrekli, İnel ve Balım, 2012; Mazlum ve Yiğit, 2017). Diğer önemli değişikliklerin başında gelen konu ve kazanımların sınıflar arasında ayrılmasına örnek olarak, 1şık ve ses konusu verilebilir. 2013 programında bu iki konu aynı ünite ile aynı sınıf düzeyinde verilirken, 2018 programında konular ayrılmış ve 1şık beşinci sınıfa, ses ise altıncı sınıfa taşınmıştır. $\mathrm{Bu}$ değişiklik, öğrencilerin tek bir kavram üzerinden daha derinlemesine bilgi edinebilmesi adına oldukça faydalı olarak kabul edilebilir. Diğer yandan, konu alanının tüm sınıf düzeylerine eşit ağırlıklı olarak dağıtılmasının sarmal öğrenme çerçevesinde daha faydalı olabileceği düşünülmektedir. Ünite başlıklarında yapılan değişikler ise genellikle ünite başlıklarının daha kapsamlı olması yönünde olurken, konu ya da kavramların ünite başlığı olarak ele alındığı veya mevcut ünitelerin yeni öğretim programından kaldırıldığı durumlar da görülmektedir. Örneğin, “canlılar ve yaşam” konu alanı için "vücudumuzdaki sistemler ve sağllğg” ünitesine, 2013 öğretim programında ünite başlığı olarak değil, konu içerikleri veya kazanımları düzeyinde yer verilirken; 2018 öğretim programında ünite başlığı olarak yer verilmiştir. Bu şekilde bazı konuların ayrıca bir ünite başlığı altında verilmesinin, konuya genel bir bakış açısı sağlamanın yanı sıra konuyu ön plana çıkararak öğretmenler ve öğrenciler için konunun önemine vurgu yapmaya fayda sağladığı söylenebilir.

21. yüzyıl becerileri ve sürdürülebilir kalkınma bilincinin kazandırılmasına yönelik hedefler dikkate alındığında, bu amaca hizmet eden kazanımlara ayrılan sürenin azaltılmasından ziyade en azından ders saatlerinin 2013 öğretim programında olduğu haliyle 
bırakılmasının gerekli olduğu düşünülmektedir. Benzer şekilde, atıklar ve geri dönüşüm gibi hem ulusal hem de küresel düzeyde ciddiyeti gün geçtikçe artan bir sosyobilimsel durumun öğretmen temelli biçimde ifade edilmesinin, öğrencilere konuya yönelik bilinç ve farkındalık kazandırılması için olumsuz etki yapabilecek bir değiş̧iklik olduğu düşünülmektedir (Bakırc1, Artun, Şahin ve Sağdıç, 2018; Çalık ve Eames, 2012). Diğer yandan, asit yağmurları gibi bir çevre probleminin etkilerine yönelik yapılan değişikliklerin, öğrencilerin sorunları fark etmenin ötesinde, onlara sorgulama, yorumlama ve problem çözmeye yönelik fikir yürütme eylemlerinin gerçekleştirilmesine yönelik bir öğrenme ortamının sağlanmasına hizmet edeceği düşünülmektedir. Bu husus, günümüz toplumlarında küresel düzeyde çevresel bilinç düzeyi ve farkındalığı yüksek olan, sorunlara olası çözümler üretebilen bireylerin yetiştirilmesi için oldukça önemli bir adım olarak görülmektedir (Çalık ve Coll, 2012; Gauld, 2005; Güven 2017; Kıryak ve Özdilek, 2016). Bu duruma paralel olarak, yenilenebilir ve yenilenemez enerji kaynakları ifadelerinin 2018 öğretim programında konu kavramları arasında da ifade edilmiş olması, sürdürülebilirlik ve kaynakların etkili kullanımına yönelik hem öğretmenlerin hem de öğrencilerin farkındalıklarının artırılması adına atılmış olumlu bir adım olarak görülebilir. Nitekim, eğitim ortamlarında geçirilecek süreçlerin sürdürülebilirlik ve çevre bilincinin kazandırılması için en etkili yollardan olduğu düşünülmektedir (Kıryak ve Çalık, 2018). Ayrıca, öğrencileri toplum için harekete geçen bireyler olarak yetiştirmeye yönelik yapılan değişikliklerin, onların sivil toplum kuruluşlarının çalışmaları hakkında fikir sahibi olmaları ve bu kuruluşların yürüttükleri faaliyetlere destek verme isteği duymalarının sağlanması adına olumlu etki yapacağı düşünülmektedir.

\section{Sonuçlar}

2013 ve 2018 Fen Bilimleri Dersi Öğretim Programlarının genel eğilimleri ve öğrenme alanındaki değişimlerin karşıllaştırılması amacıyla yapılan bu çalışmada elde edilen sonuçlar aşağıda maddeler halinde ifade edilmiştir:

1. 2018 Fen Bilimleri Dersi Öğretim Programı’nın genel amaçları arasında yer almadığı belirlenen üç amaç incelendiğinde, bu amaçların bilimin doğasına işaret ettiği görülmüştür. Benzer şekilde, kazanım ifadelerinde de bilimsel ve teknolojik gelişim ve bilim tarihine yönelik ifadelere yeni programda yer verilmediği belirlenmiştir. $\mathrm{Bu}$ doğrultuda, 2018 öğretim programı ile bilimi ve bilimin rolünün ne olduğunu, bilim 
insanlarını ve onların bilim tarihindeki rolünü anlama ve bilimsel yönteme yönelik anlayışları kazandırmaktan uzaklaşıldığı ifade edilebilir.

2. 2018 öğretim programının amaçlarında üst düzey düşünme alışkanlıklarının kazandırılmasına yönelik ifadelerin yer aldığı belirlenmiştir. Bu durumla paralel olarak bilgi düzeyindeki kazanım ifadelerinin analiz ve sentez düzeyinde yeniden ifade edildiği görülmüştür. Bu bağlamda, 2018 öğretim programındaki değişikliğin, öğretmenlerin öğrencilerinin üst düzey becerilerini kullanabilecekleri öğrenme süreçlerini ve ortamlarını planlamalarına olanak sağlayacağı düşünülmektedir.

3. 2018 öğretim programında araştırma-sorgulama stratejisinin yanı sıra bilginin transferine dayalı öğretim stratejisine de vurgu yapıldığı ve kazanımların da bu doğrultuda öğrencilerin bilgilerini farklı derslerin içerikleriyle ilişkilendirebilecekleri şekilde tasarlandığı belirlenmiştir. Bu bağlamda, bilginin transferini destekleyecek nitelikte hazırlanan öğretim programının, disiplinlerarası yaklaşımı hedeflediği sonucuna ulaşılabilir.

4. 2018 öğretim programının temel amaçlarına, fen ve mühendislik uygulamalarına yönelik temel bilgilerin kazandırılması amaçlı bir maddenin ve beceri öğrenme alanına da mühendislik ve tasarım becerilerinin eklendiği belirlenmiştir. Benzer şekilde, bilgiyi ürüne dönüştüren ve bunu değerlendiren birey vurgusunun sıklıkla ifade edildiği ve fen bilimleri öğretmeninin rolünde bilim, teknoloji, mühendislik ve matematiğin bütünleştirilmesi için öğrencilere rehberlik yapmanın gerekli olduğunun belirtildiği görülmüştür. Öğretim programının bu genel eğilimiyle uyumlu olarak kazanımlarda da ürün tasarlama ya da ürünü yapma gibi çeşitli değişikliklerin yapıldığı tespit edilmiştir. $\mathrm{Bu}$ bağlamda, yeni öğretim programının disiplinlerarası yaklaşım ve pratik uygulamalarla günlük yaşama yeniliklerin katılması fikrini benimseyen FeTeMM yaklaşımına işaret ettiği sonucuna ulaşılabilir.

5. FeTeMM vurgusunun yoğun bir biçimde öğretim programına entegre edildiği, ancak öğretmenlerin bu bağlamda öğretim süreçlerini nasıl tasarlayacakları ve yürütecekleri ile ilgili detaylı bilginin olmadığı göz önünde bulundurulduğunda, öğretmenlerin FeTeMM bağlamında gerçekleştirilmesi beklenen süreçlerde istenilen düzeye ulaşma konusunda sorunlar yaşama ihtimallerinin olabileceği düşünülmektedir.

6. Öğretim programının geneline bakıldığında, öğrencilerin eleştirel düşünme, sorgulama, tartışma, iletişim süreçlerine katılma gibi becerilerinin geliştirilmesine yönelik 
ifadelerin programda dikkate değer şekilde vurgulanması, yeni öğretim programının tüm sınıf düzeylerindeki öğrencilerin 21. yüzyıl becerilerinin geliştirilmesi adına olumlu etkilerinin olacağı düşüncesinin oluşmasına yol açmaktadır.

\section{Öneriler}

1. 2018 eylül ayından itibaren tüm sınıf düzeylerinde uygulanmaya başlanan öğretim programındaki en büyük değişikliğin ve dikkat çeken hususun fen bilimlerinin matematik, teknoloji ve mühendislik ile ilişkilendirilmesi olduğu görülmektedir. Öğrencilerin bilgiyi araştırma, sorgulama ve tartışma yeterliklerinin de ötesinde ürüne dönüştürme becerilerinin geliştirilmesi gerektiği üzerinde yoğunlaşılmış olmasına rağmen pratikte gerçekleştirilmesinin zor olacağı düşünülmektedir. Bu nedenle, ülkemiz koşullarında ve öğretmenlerin bu amaca ve uygulamalara yönelik herhangi bir eğitim almamış olmamaları da göz önünde bulundurulduğunda, bu becerileri kazanmalarını ve bu becerileri öğretecek pedagojik bilgiye sahip olmalarını sağlayacak hizmet içi eğitimlerin periyodik olarak düzenlenmesi önerilmektedir.

2. Meslekteki öğretmenlerin istenen amaçlara ulaşabilmesi için hizmet içi eğitimlerin yanı sıra interaktif destek sistemleri ve rehber kitaplar aracılığıyla da 21. yüzyıl becerileri ve FeTeMM eğitimi hakkında bilgiye her durum ve koşul altında kolayca ulaşabilecekleri uygulama ve materyallerle de desteklenmesinin uyum sürecini destekleyeceği düşünülmektedir.

\section{Makalenin Bilimdeki Konumu}

Matematik ve Fen Bilimleri Eğitimi/Fen Bilgisi Eğitimi

\section{Makalenin Bilimdeki Özgünlüğü}

2018 yılında Fen Bilimleri Dersi Öğretim Programında yapılan değişiklikler ve bu değişikliklerin öğretim programının hangi özelliklerine yönelik yapıldığının belirlenmesi, programın analiz edilme gerekliliğini açığa çıkarmıştır. Analiz sürecinde elde edilen bulguların yorumlanabilmesi için yerine geldiği öğretim programıyla karşılaştırılması gerekmektedir. $\mathrm{Bu}$ bağlamda, alanyazında iki öğretim programının karşılaştırılmasına yönelik yapılan çalışmaların programları mühendislik ve tasarım becerileri ile FeTeMM boyutu altında, bir çalışmanındı programları temel öğeler bağlamında incelediği belirlenmiştir. Ancak bu çalışmada, her iki programı genel yaklaşımlar ve bilgi öğrenme alanındaki değişimler açısından karşılaştırılarak ve değişimleri 2023 vizyonu da dikkate alınarak yorumlanmaya çalışmıştır. Bu doğrultuda, 
2013 ve 2018 öğretim programları genel yaklaşımlar ve bilgi öğrenme alanında yapılan değişiklikler ve bunların alt boyutları altında karşılaştırılarak incelenmiştir.

\section{Kaynaklar}

Aikenhead, G. S. (2006). Science education for everyday life: Evidence-based practice. Teachers College Press.

Akaygun, S. \& Aslan Tutak, F. (2016). STEM images revealing stem conceptions of pre-service chemistry and mathematics teachers. International Journal of Education in Mathematics, Science and Technology, 4(1), 56-71.

Akbaş, O. (2007). Türk Milli Eğitim sisteminin duyuşsal amaçlarının (değerlerinin) ilköğretim 8. sınıf öğrencilerinde gerçekleşme derecesinin değerlendirilmesi. (Ed. R. Kaymakcan, S. Kenan, H. Hökelekli, Ş. Arslan, M. Zengin) Değerler ve Eğitimi Uluslararası Sempozyumu (ss. 673-695). İstanbul: Dem Yayınları.

Akgündüz, D., Aydeniz, M., Çakmakçı, G., Çavaş, B., Çorlu, M. S., Öner, T. ve Özdemir, S. (2015). STEM Eğitimi Türkiye Raporu. İstanbul: Scala Basım.

Akgündüz, D. ve Ertepınar, H. (Ed). (2015). STEM eğitimi Türkiye raporu: Günün modası mı yoksa gereksinim mi? Aydın Üniversitesi, İstanbul, Türkiye. http://www.aydin.edu.tr/belgeler/IAUSTEM-Egitimi-Turkiye-Raporu2015.pdf adresinden 20 Mart 2018 tarihinde edinilmiştir.

Aslan-Tutak, F., Akaygun, S. ve Tezsezen, S. (2017). İşbirlikli FeTeMM (Fen, Teknoloji, Mühendislik, Matematik) eğitimi uygulaması: kimya ve matematik öğretmen adaylarının FeTeMM farkındalıklarının incelenmesi. Hacettepe Üniversitesi Eğitim Fakültesi Dergisi, 32(4), 794-816.

Ayas, A., Çepni, S., Akdeniz, A. R., Özmen, H., Yiğit, N. ve Ayvacı, H. Ş. (2016). Kuramdan Uygulamaya Fen ve Teknoloji Öğretimi. (Ed. S. Çepni), (16. Bask1). Ankara: Pegem Akademi Yayıncılık.

Bahar, M., Yener, D., Y1lmaz, M., Emen, H. ve Gürer, F. (2018). 2018 Fen bilimleri öğretim programı kazanımlarındaki değişimler ve fen teknoloji matematik mühendislik (STEM) entegrasyonu. Abant İzzet Baysal Üniversitesi Eğitim Fakültesi Dergisi, 18(2), 18 (2), 702-735.702-735.

Bağcı-Kılıç, G., Haymana, F. ve Bozyılmaz, B. (2008). İlköğretim fen ve teknoloji dersi ögretim programının bilim okuryazarlığı ve bilimsel süreç becerileri açısından analizi. Eğitim ve Bilim, 33(150), 52-63. 
Bakırcı, H., Artun, H., Şahin, S. ve Sağdıç, M. (2018). Ortak bilgi yapılandırma modeline dayalı fen öğretimi aracılığıyla yedinci sınıf öğrencilerinin sosyobilimsel konular hakkındaki görüşlerinin incelenmesi. Eğitimde Nitel Araştırmalar Dergisi, 6(2), 207-237.

Bakırcı, H., Çepni, S. ve Yıldız, M. (2015). Ortak bilgi yapılandırma modelinin altıncı sınıf öğrencilerinin akademik başarılarına etkisi: Işık ve ses ünitesi. Dicle Üniversitesi Ziya Gökalp Eğitim Fakültesi Dergisi, 26, 182-204.

Bakırcı, H. ve Kutlu, E. (2018). Fen bilimleri öğretmenlerinin FeTeMM yaklaşımı hakkındaki görüşlerinin belirlenmesi. Türk Bilgisayar ve Matematik Eğitimi Dergisi, 9(2), 367-389.

Çengelci, T., Hancı, B. ve Karaduman, H. (2013). Okul ortamında değerler eğitimi konusunda öğretmen ve öğrenci görüşleri. Değerler Eğitimi Dergisi, 11(25), 33-56.

Çolakoğlu, M. H. ve Günay-Gökben, A. (2017). Türkiye’de eğitim fakültelerinde FeTeMM (Stem) çalışmaları. Informal Ortamlarda Araştırmalar Dergisi, 3, 46-69.

Demirbaş, M. (2008). 6. sınıf fen bilgisi ve fen ve teknoloji öğretim programlarının karşılaştırılmalı olarak incelenmesi: Öğretim öncesi görüşler. Uludağ Üniversitesi Ĕ̆itim Fakültesi Dergisi, 21(2), 313-338.

Dedes, C. \& Ravanis, K. (2008). History of science and conceptual change: The formation of shadows by extended light sources. Science \& Education, 18(9), 1135-1151.

Demirci, N. \& Ahçı, M. (2016). University students' conceptual understanding on the subjects of light and optics. Necatibey Faculty of Education Electronic Journal of Science \& Mathematics Education, 10(1), 142-181.

Eroğlu, S. ve Bektaş, O. (2016). STEM eğitimi almış fen bilimleri öğretmenlerinin stem temelli ders etkinlikleri hakkındaki görüşleri. Eğitimde Nitel Araştırmalar Dergisi, 4(3), 43-67.

Evrekli, E., İnel, D. ve Balım, A. G. (2012). Kavram ve zihin haritası kullanımının öğrencilerin kavramları anlama düzeyleri ile fen ve teknolojiye yönelik tutumları üzerindeki etkileri. Abant İzzet Baysal Ĕ̈itim Fakültesi Dergisi, 12(1), 229-250.

Gauld, C. F. (1982). The scientific attitude and science education: A critical reappraisal. Science Education, 66(1), 109-121.

Gauld, C. F. (2005). Habits of mind, scholarship and decision making in science and religion. Science \& Education, 14(3-5), 291-308.

Güneş-Koç, S. R. ve Kayacan, K. (2018). Fen bilimleri öğretmenlerinin 2018 fen bilimleri öğretim programında yer alan mühendislik ve tasarım becerilerine ilişkin görüşlerinin belirlenmesi. Electronic Turkish Studies, 13(19), 865-881. 
Güven, O. (2017). Fen bilgisi ögretmen adaylarının çevre problemlerine yönelik bilimsel düşünme alışkanlıklarının incelenmesi (Yayımlanmamış yüksek lisans tezi). Karadeniz Teknik Üniversitesi, Eğitim Bilimleri Enstitüsü, Trabzon

Heering, P. (2000). Getting shocks: Teaching secondary school physics through history. Science \& Education, 9(4), 363-373.

Karaman, P. ve Karaman, A. (2016). Fen bilimleri öğretmenlerinin yenilenen fen bilimleri öğretim programına yönelik görüşleri. Erzincan Üniversitesi Eğitim Fakültesi Dergisi, 18(1), 243-269.

Kıryak, Z., Candaş, B. \& Ünal, S. (2018, September). Teaching science through the storytelling based on the history of science: Tesla and Volta cases. Paper presented at XI. International Congress of Educational Research, 17-19 September 2018, Krakow, Poland.

Kiryak, Z. \& Çalik, M. (2018). Improving grade 7 students’ conceptual understanding of water pollution via common knowledge construction model. International Journal of Science and Mathematics Education, 16(6), 1025-1046.

Kıryak Z. ve Özdilek Z. (2016, Eylül). Tahmin-açıklama-gözlem-açıklama yöntemine göre gerçekleştirilen öğretimin ortaokul 8. sınıf öğrencilerinin asit yağmurları ile ilgili kavramsal anlama düzeylerine etkisi. XII. Fen Bilimleri ve Matematik Eğitimi Kongresi’nde sunulan sözlü bildiri, Trabzon.

Kolstø, S. D. (2008). Science education for democratic citizenship through the use of the history of science. Science \& Education, 17(8-9), 977-997.

Koştur, H. İ. (2017). FeTeMM eğitiminde bilim tarihi uygulamaları: El-Cezeri örneği. Başkent University Journal of Education, 4(1), 61-73.

Kubat, U. (2015). Beşinci sınıf fen bilimleri öğretim programının içerik ve kazanım ilişkisinin öğretmen görüşlerine göre değerlendirilmesi. International Periodical for the Languages. Literature and History of Turkish or Turkic, 10(11), 1061-1070.

Kubli, F. (1999). Historical aspects in physics teaching: Using Galileo's work in a new Swiss project. Science \& Education, 8(2), 137-150.

Lederman, N. G. (1998). The state of science education: subject matter without context. The Electronic Journal of Science Education, 3(2), 1-6.

Mazlum, E. ve Yiğit, N. (2017). Işık konusundaki kavram bilgisi göstergelerinin ve öğretim kanallarının akran öğretimi uygulamalarıyla incelenmesi. Hacettepe Üniversitesi Ĕgitim Fakültesi Dergisi, 32(2), 295-311. 
YYÜ Eğitim Fakültesi Dergisi (YYU Journal of Education Faculty), 2019; 16(1):1668-1697, http://efdergi.yyu.edu.tr

MEB (2018). İlköğretim kurumları fen bilimleri dersi öğretim programı. Ankara: Talim ve Terbiye Kurulu Başkanlığı.

National Research Council (2005). Facilitating Interdisciplinary Research, Washington, DC: National Academy of Sciences. www.nap.edu/catalog/11153.html adresinden 2 Haziran 2018 tarihinde edinilmiştir.

Özata-Yücel, E. ve Özkan, M. (2013). Fen bilimleri programının 2005 fen ve teknoloji programıyla çevre konularının işlenişi açısından karşılaştırılması. Uludağ Üniversitesi Eğitim Fakültesi Dergisi, 26(1), 237-265.

Özdemir, H. (2006). Illkögretim okulları 4. ve 5. sinıf fen bilgisi ögretim programlarında karşılaşılan sorunlar ve çözüm önerilerine ilişkin ögrretmen görüşleri (Konya ili örneklemi) (Yayınlanmamış doktora tezi), Selçuk Üniversitesi, Sosyal Bilimler Enstitüsü, Konya.

Özcan, H. ve Düzgünoğlu, H. (2017). Fen bilimleri dersi 2017 taslak öğretim programına ilişkin öğretmen görüşleri. International Journal of Active Learning, 2(2), 28-48.

Rutheford, F. J. \& Ahlgren, A. (1990). Science for all Americans. Oxford University Press.

Tekbıyık, A. ve Akdeniz, A. R. (2008). İlköğretim fen ve teknoloji dersi öğretim programını kabullenmeye ve uygulamaya yönelik öğretmen görüşleri. Necatibey Eğitim Fakültesi Elektronik Fen ve Matematik Eğitimi Dergisi, 2(2), 23-37.

Timur, S., Karatay, R. ve Timur, B. (2013). 2005 ve 2013 yılı fen dersi öğretim programlarının karşılaştırılması. Adıyaman Üniversitesi Sosyal Bilimler Enstitüsü Dergisi, 6(15), 233264.

Toraman, S. ve Alcı, B. (2013). Fen ve teknoloji öğretmenlerinin yenilenen fen bilimleri dersi öğretim programına ilişkin görüşleri. EKEV Akademi Dergisi, 56(56), 11-22.

Yıldırım, C. (2012). Bilim tarihi. Remzi Kitabevi, İstanbul

Yıldırım, A. ve Şimşek, H. (2013). Sosyal bilimlerde nitel araştırma yöntemleri. Ankara: Seçkin Yayınevi.

Y1lmaz, N. ve Pekbay, C. (2017, May). Fen bilgisi ve ilköğretim matematik öğretmen adaylarıyla yapılan bir FETEMM etkinliğinin tanıtılması üzerine bir çalışma. II. International Congress on Political, Economic and Social Studies kongresinde sözlü bildiri, Sarajevo, Bosnia Herzegovina. 
YÖK (2018). Fen bilgisi öğretmenliği lisans programı. http://www.yok.gov.tr/documents/10279/41805112/Fen_Bilgisi_Ogretmenligi_Lisans_Progra $\underline{\text { mi.pdf }}$ adresinden alınmıştır.

\section{Summary}

\section{Statement of Problem}

To educate individuals who are expected from education in the modern societies who are questioning, interpreting the knowledge, thinking critically, adapting the information to the daily life and solving the problems that they face, having 21st century skills, rather than individuals who learn by memorization. In order to follow the changes on a global scale and to guide the society in this direction, governments are aiming to educate students with these skills by integrating these skills into their education systems and thus in educational programs. For educating students with 21st century skills will be possible using the constructivist approach in the teaching process which emphasizes that the student should be active, researching, questioning and structuring the knowledge. These expectations also coincide with the goal of raising science literate individuals, one of the targets of science course. Similar to the practices in the world, the curriculums have been prepared in a constructivist approach in 2004 specially to meet the expectations from the science course. Science and Technology course, which started to be implemented in schools in 2005, is important in terms of reflecting both constructivist philosophy and changes in the understanding of assessment and evaluation and, roles of student and teacher in classroom. Although the science and technology course has changed the content and implementation of classical science lesson significantly, the different problems experienced in the implementation process and the update needs in time, the change in the name and content of the course have been made in 2013. With the STEM approach that emerged with the idea of teaching the contents of science, technology, mathematics and engineering with interdisciplinary approach and the transformation of practical applications into innovations that add value to life, individuals who have these skills in our country have revealed the need to update curriculums due to the desire to raise them. Accordingly, in 2018, a new curriculum of science course was published in Turkey. In this study, it is aimed to examine the 2013 and 2018 science curriculum teaching programs in terms of various variables, in this respect, to interpret the 2018 curriculum in different ways and to present suggestions that are thought to benefit teachers, researchers and program developers. 


\section{Method}

In this study, document analysis method was used from qualitative research approaches. The data obtained from the 2013 and 2018 science curriculum were examined under two general themes. After the curriculums were analyzed separately by four researchers under the determined themes, the results were compared and reliability coefficient was calculated as $98 \%$.

2013 and 2018 science course curriculums were examined under two main titles as "changes in the approaches" and "changes in the knowledge learning areas". The data obtained from examining the aims, the learning domains, teacher-student's roles, methods and strategies, and assessment and evaluation approaches were determined. Under the second titles, the changes in the number and structure of curriculum targets, learning domains, the class levels and units, course hours were presented.

\section{Findings}

When the curriculums were examined in terms of general aims and tendencies, it was seen both curriculums aim to educate all individuals as science literate. It was determined that some subtitles of knowledge learning domain in 2013 curriculum has been changed in 2018 curriculum, for example, "matter and changes" subtitle was expressed as "nature of matter" in new curriculum. In both curriculums, a holistic perspective was adopted in terms of learning and teaching theories and practices, that the student was responsible for his/her own learning and should be active in the learning process. Also, in 2018 curriculum it was emphasized transfer of knowledge to other subjects or courses in addition to inquiry-based approach which allows construct the knowledge own mind.

In the 2018 curriculum, it is stated that assessment and evaluation practices that should consider the individual differences. 330 targets of 2013 curriculums were decreased 302 in 2018 curriculums. When examined the changes in the verbs of targets, it was seen that some of the targets were level up to the higher cognitive levels, while some of them were transferred to the lower levels. It is seen that some subject titles and targets exchanged between different class levels. For example, “force and energy” unit has been transferred from seventh grade to eighth grade.

\section{Discussion and Conclusion}

With this study, it is aimed to examine the 2013 and 2018 science curriculum teaching programs in terms of various variables. In terms of general approaches of the 2018 curriculum, two main changes drew attention. First one is the addition of values education as a subgoal 
which were given latent in the previous curricula. This addition is seen as an important step to make students gain values which have effect on both the learning and the behavior of the individuals and should be brought to students by school for the characteristic, selfness and moral development of the students. The second important change is the addition of the STEM education not only in the subgoals, but also in the role of student and teacher. The Report of the STEM Education in Turkey addressed that there is an urgent need of development of educational policies and programs which is mostly satisfied with this 2018 curriculum. However, there are already some problems about STEM education in Turkey such as insufficient time and materials to make an effective STEM education, low knowledge level of science teachers and inadequate pre-service training in terms of both theoretical and practical. As a result of the study, STEM education is intensively integrated to the curriculum, however, some problems related with the teachers' lack of knowledge in terms of theoretical and practical are foreseen. To make students compete with the 21. century skills, it is important to make student gain critical thinking, inquiry, argumentation and communication skills. Teachers should be supported with guidebook and interactive materials to ease the orientation process. 